\title{
The Double Effect of employment and labor relations caused by Economic structure transformation during the 13th Five-Year Plan period \\ Mengmeng Guo
}

\author{
No.6 Xueyuan domitory,Beijing Jiaotong University,No.3 ShangYuanCun,Haidian District,Beijing \\ City,China
}

\section{guomengmeng1993@163.com}

Keywords: labor relations, structure transformation, 13th Five-Year Plan period.

\begin{abstract}
This document explains the double effect of employment and labor relations caused by Economic structure transformation during the 13th Five-Year Plan period.The Central Economic Working Conference in 2014 pointed out that Chinese economy is spreading from rapid growth to muted growth and the pattern of economic development is spreading from the scale type speed type to quality efficiency of extensive growth and intensive growth. The economic structure are mainly adjusting from incremental capacity to the stock, and optimizing the depth of the incremental coexist adjustment. The economic development is adjusting from traditional growth to new kinds of growth.
\end{abstract}

\section{Introduction}

Under the background of globalization, during the 13th Five-Year Plan period, the external risk which brought by the international financial crisis has been a wake-up call for Chinese economic development. Since the Chinese reform and opening, Chinese economy has been undergoing 30 years of rapid growth.At the same time, the great reform "bonus" also accumulated a series of deep structural problems:,spelling consumption resources, spelling extensive development pattern of the cheap labor has been unsustainable. Chinese economic development is coming into the "new normal".

Compared with "the twelfth five-year period" , during the period of the 13th Five-Year Plan ", the characteristic of the Chinese economy is the economic transformation and innovation. This means that from high speed to high speed economic growth, deepening of restructuring ongoing transfer way, all of these have a direct and profound influence on labor relations. The adjustment of economic structure impact on labor relation has both positive and negative side. during the period of the 13th Five-Year Plan ", in order to construct harmonious labor relations, we need to judge on the main economic factors first and offer the rational cause.

\section{Employment and labor relations}

2.1 The Economic Downturn Leads to Intensive Market Competition, Forced the Enterprises Attache Great Importance to Talent and Innovation. According to the supply and demand analysis from partial provinces and cities in the national talent services market, by 2015 , the countries continue to be increased. to the number of unit of choose and employ persons, the number of job providing is also increasing, labor market conditions is optimistic.

Table 1: The overall market supply and demand situation in 2013-2015

\begin{tabular}{|l|l|l|l|l|}
\hline quarter & $\begin{array}{l}\text { The number } \\
\text { of employers } \\
(\mathrm{m})\end{array}$ & $\begin{array}{l}\text { working } \\
\text { positions }(\mathrm{m})\end{array}$ & $\begin{array}{l}\text { Job seekers } \\
(\mathrm{m})\end{array}$ & $\begin{array}{l}\text { Talent } \\
\text { supply and } \\
\text { demand } \\
\text { ratio }\end{array}$ \\
\hline $\begin{array}{l}\text { the first quarter of } \\
2015\end{array}$ & 17.8 & 347.4 & 684.4 & 1.97 \\
\hline $\begin{array}{l}\text { the fourth quarter } \\
\text { of 2014 }\end{array}$ & 15.9 & 269 & 532.4 & 1.98 \\
\hline
\end{tabular}




\begin{tabular}{|l|l|l|l|l|}
\hline $\begin{array}{l}\text { the third quarter } \\
\text { of } 2014\end{array}$ & 18.4 & 319 & 638 & 2 \\
\hline $\begin{array}{l}\text { the second } \\
\text { quarter of 2014 }\end{array}$ & 19 & 372.5 & 747.6 & 2.01 \\
\hline $\begin{array}{l}\text { the first quarter of } \\
2014\end{array}$ & 19.2 & 409.7 & 818 & 2 \\
\hline $\begin{array}{l}\text { the fourth quarter } \\
\text { of 2013 }\end{array}$ & 17.5 & 358.7 & 712.3 & 1.99 \\
\hline $\begin{array}{l}\text { the third quarter } \\
\text { of 2013 }\end{array}$ & 20.6 & 361.2 & 720.6 & 2 \\
\hline $\begin{array}{l}\text { the second } \\
\text { quarter of 2013 }\end{array}$ & 21.6 & 418.4 & 840.3 & 2.01 \\
\hline
\end{tabular}

Data sources: Chinsese human resources market network

( http://www.chrm.gov.cn/Content/843/2015/8/98257.html)

According to the country's 100 city human resources market supply and demand information,it shows that in recent years, the technical level of openings ratio of the number of job were greater than 1 , and the number is growing. In the fourth quarter of 2014, the ratio of senior engineer, senior technicians, technicians, engineers were 2.10, 2.0, 1.91, 1.81 [Zheng Dongliang, economic construction of a harmonious labor relations under the new normal challenges and countermeasures]. As the demand of talent in companies is increasing, half almost vacancies .

\subsection{The Industry Promoting Create More Employment Opportunities and Obviously} Changed the Demand Structure. At the end of 2014, above all of the national employees, employees from the first industry accounted for 29.5\%; employees from the second industry accounted for $29.9 \%$; employees from the third industry accounted for $40.6 \%$. It is the first time that the third industry coming to more than forty percent in absorbing employees, becoming the absolutely main force. Please see table 2 .

In 2011, the number of the employees from the third industry were more than the first industry, becoming the first place with $35.7 \%$. Later, along with the economic structure adjustment, the employees from the third industry is increasing. The number of emplyees from the first industry declined. This shows that Chinese employment structure is adjusting from the first industry to the tertiary industry accounted for the bulk of the modern employment structure transformation. Contrasted with the high-income countries around the world, its primary industry employment proportion is around $10 \%$, the third industry counts more than $60 \%$ of the total employment. In contrast, China's first industry employment proportion are still high, the third industry employment also has the very big development space.

Table 2:The percentage between industry employment in 2010-2014

\begin{tabular}{|l|l|l|l|l|l|}
\hline $\begin{array}{l}\text { Employment } \\
\text { structure } \\
(\%)\end{array}$ & 2010 & 2011 & 2012 & 2013 & 2014 \\
\hline Primary industry & 36.7 & 34.8 & 33.6 & 31.4 & 29.5 \\
\hline Secondary industry & 28.7 & 29.5 & 30.3 & 30.1 & 29.9 \\
\hline Tertiary industry & 34.6 & 35.7 & 36.1 & 38.5 & 40.6 \\
\hline
\end{tabular}

Source: Chinese statistical yearbook

From the point of Chinese employment quantity, the number is not very large, especially since the "twelfth five-year" period, the number is less than 3 million in a year on average. Investigated its reason, mainly lies on the employment in three sectors between the reconfiguration of offset the net increase of employment, the agricultural sector shrinking employment scale, makes the non-farm sector employment increase was partly offset. At present, the tertiary industry has become the main sector of employment growth, the third industry employment growth of more than $70 \%$ of the total employment growth. Please see table 3. 
Table 3 : The average change Scale of industry and employment (ten thousand)

\begin{tabular}{|l|l|l|l|l|}
\hline & $\begin{array}{l}\text { Total } \\
\text { employmen } \\
\mathrm{t}\end{array}$ & $\begin{array}{l}\text { Primary } \\
\text { industry } \\
\text { employment }\end{array}$ & $\begin{array}{l}\text { The second } \\
\text { industry } \\
\text { employment }\end{array}$ & $\begin{array}{l}\text { The } \\
\text { industry } \\
\text { employment }\end{array}$ \\
\hline $\begin{array}{l}\text { The tenth five-year } \\
\text { project 2001 2005 }\end{array}$ & 512 & -520 & 309 & 723 \\
\hline $\begin{array}{l}\text { The eleventh five-year } \\
\text { project 2006 2010 }\end{array}$ & 292 & -1102 & 815 & 579 \\
\hline $\begin{array}{l}\text { The twelveth five-year } \\
\text { project } \\
\text { 2011 2013 }\end{array}$ & 291 & -1253 & 443 & 1101 \\
\hline
\end{tabular}

\section{Quotation of Materials}

Economic factors, the first impact on labor relation is the economic and social policy factors: wen-guang bo [1] (2016), "forward, with the deepening of the reform of the supply side, and the employment structure and labor relationship has a larger differentiation effect." ; Scholars Zheng Dongliang [2] (2015) : "much starker choices-and graver consequences-in period, the characteristic of the our country economy is the economic transformation and innovation. This means that the economic growth from high speed to high speed, the deepening of restructuring ongoing transfer way, all of these have a direct and profound influence on labor relations. The adjustment of economic structure impact on labor relation has both positive and negative side." ; Yao Angsheng [3] (2016), "employee allocation problem is to capacity of the most important problems of labor relations, to production enterprise is mainly state-owned enterprises, the overall stability of labor relations, but the worker disadvantaged reality, there is no substantive change. Enterprise in staff resettlement project or related problems couldn't handle, could lead to labor conflicts." ; Scholar Chen jing, He Xing, Jin Shubin [4] (2015) explores the informal employment in urban migrant workers labor relations exist many characteristics, of "informal employment in urban migrant workers low occupational hierarchy, the work is not stable labor relations, labor contract signing rate is low, but a lot of momentum, the lack of skills training and career advancement opportunities, lack of exercised to ensure deterioration, loss of trade union organizations, human rights and labor standards does not reach the designated position, imperfect labor dispute processing system, labor disputes are difficult to resolve in time etc, these characteristics seriously hindered the construction of harmonious labor relations."

\section{Summary}

On the one hand, overall employment population is stable in 2015. From the urban and rural structure, urban resident population is 771.16 million, an increase of 22 million people compared with last year. Rural resident population is 603.46 million people, which decread 15.2 million people. At the end of the national employment personnel 774.51 million people, including 404.1 million people in the town of employment. [source: China statistical yearbook 2015] The generally stable employment population in 2015 was profited to the development of the third industry, service industry while investment is not much, but many are labor-intensive industry. Which make great effect to ease the employment pressure and played a good role on increasing the quantity of employment.

On the other hand, with the continuous deepening of the industry reform, the employment is flowing to the tertiary industry.In China, some extensive, low efficiency and energy-intensive enterprises need to shut down. Some jobs will be adjusted, some workers transferred twice employment problem. With the transformation and upgrading of economic structure, employment transfer, differentiation, increases the income distribution gap between different social groups, and enhance the sense of injustice of some people. With the implementation of the developing innovation drive strategy, new industry develop fast, the new formats appear quickly.more diversity in the form of labor relations, labor relations adjustment will become more complex. 


\section{Acknowledgement}

This research was financially supported by the National Natural Science Foundation of China (Grant NO. 00000000) and the Fundamental Research Funds for Central University (Grant NO.TD2010-2).

\section{References}

[1] John T. Dunlop, Industrial Relations System, New York; Henry Holt, 1958, P16, P14. Arthur M. Ross, Trade Union Wage Policy, Berkeley: University of California Press， 1948， P7

[2] C. J. Margerison, "What to We Mean by Industrial Relations-A Behavioral Science Approach", British Journal of Industrial Relations 7(2) (July 1969), P273.

[3] Marcus. H. 5andver, Labor Relations; Process and Outcomes， 1987， P21

[4] J Harry C. Katz, Thomas A. Kochan and Mark R. Weber .Assessing the Effects of Industrial Relations Systems and Efforts to Improve the Quality of Working Life on Review and Comparative Analysis[J]. Industrial

[5] JR Norsworthy, CA.Zabala. Worker Attitudes and the Cost of Production: Hypothesis Tests in an Equilibrium Model[J]. Economic Inquiry, 1990， 28(1):57-78

[6] Joel Cutcher-Gershenfeld, Patrick McHugh, Donald Power. Collective Bargaining in Small Firms: Preliminary Evidence of Fundamental Change[J].

[7] Jody.Hoffer.Gittell, Andrew.Von. Nordenflycht, Thomas A.Kochan. Mutual Gainsor Zero Sum? Labor Relations and Firm Performance in the Airline Industry

[8] Robert Buchele, Jens Christiansen. Do employment and income security cause unemployment? A comparative study of the US and the E-4[J]. Cambridge Journal of Economics， 1998，22(1): $117-136$

[9] Elisabetta Magnan, David Prentice. Unionization and Input Flexibility in U.S.Manufacturing, 1973-1996[J]. Industrial and Labor Relations Review， Vol. 59， No. 3，2006， (4):386-407

[10] Corinne Bendersky. Complenentarities in Organizational Dispute Resolution Systems: How System Characteristics Affect Individuals' Conflict Experiences [J].Industrial and Labor relations Review, Vol. 60, No. 2, 2007, (1):204-224. 